\title{
June Jordan: A Third-Wave Feminist towards a Gendered- Democratic Poetics
}

\author{
Abeer Refky Seddeek \\ Associate Professor in English Literature \\ College of Language and Communication (CLC) \\ Arab Academy for Science, Technology and Maritime \\ Transport (AASTMT)
}




\section{Abstract}

The aim of the present study is threefold: to prove that the American poet June Jordan (1936-2002) is able to combine her social and political views along with her personal life to serve public causes such as political oppression, African-American identity, democracy in the US, and racial inequality; to reflect her feminist advocation of shared human rights and goals for a better society; and to underline her globalized notion of solidarity amongst the world's marginalized and oppressed in their search for democracy and freedom. The study is based on Nicky Marsh's Democracy in Contemporary US Women's Poetry (2007), its debate on third-wave feminism and democratic theory, and the complexities of being public in the US culture. The study proves that Jordan's poetry examines the discursive assumptions of democracy in the US, contributes to the democratic tradition of the US contemporary culture through the gender theory that considers citizenship and publicness as the main concepts of third-wave feminism, and suggests new democratic cultures by its variety of publics and feminist discourse. The study concludes that Jordan's feminist discourse focuses on the relation between the private, the political and the public and creates a strong public discourse capable of reforming the inequality deeply implanted in the contaminated formative discourses. As a third-wave feminist, Jordan is concerned with the conflict between a feminist and a democratic identity to form a new poetic language for being public. She adopts the gender theory that investigates the sociopolitical implications of democracy and exhibits the female identity as a societal construct. Jordan's poetry suggests new models of gendered democratic poetics and shows that social reality shapes the poet's identity through which reality is deconstructed and offered alternatives.

Key words: Feminist discourse, Gendered-democratic poetics, Political activism, The political and the personal, The public and the private, Third-wave feminism 


\section{جون جوردان : شاعرة الموجة النسوية الثالثة والشاعرية الجنسانية الديمقراطية ملخص}

ترتكز الدراسة الحالية على ثلاثة محاور أساسية، ألا وهى أولاً: إثبات أن الثاعرة الأمريكية

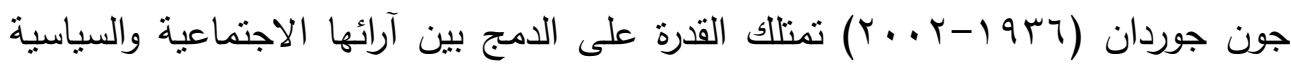
وحياتها الخاصة لخدمة قضايا عامة منل القهر السياسي، والهوية الأفريقية الأمريكية،

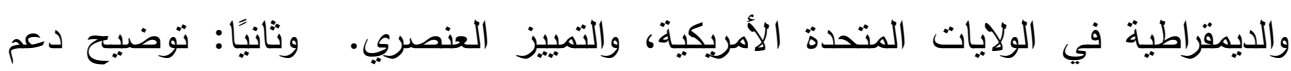
جوردان النسوي لحقوق وأهداف الإنسان المشتركة نحو مجتمع أفضل. وثالثًا: إلقاء الضوء على مفهومها عن التضامن العالمي بين المهمشين والمقهورين في العالم أثناء بحثهم عن الأنيان الديمقراطية والحرية.

وتستخدم الدراسة كتاب الكاتبة النسوية نيكي مارش "الديمقراطية في شعر الثاعرات

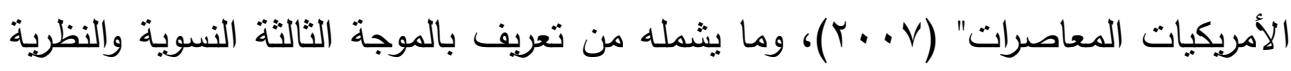
الديمقراطية وصعوبات التحول إلى الخطاب العام في التقافة الأمريكية. وتتبت الدراسة قيام جوردان بتحليل الافتراضات الخطابية حول الديمقراطية بالولايات المتحدة

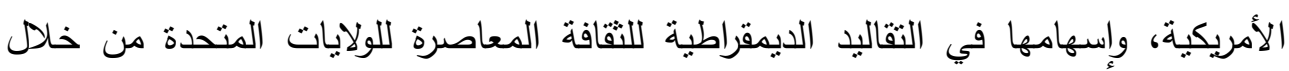
نظرية النوع التي تعتبر المواطنة والعمومية بمثابة المفهومين الرئيسيين في الموجة الثالثة النسوية، وطرحها لنقافات ديمقراطية جديدة من خلال التتوع في الآراء العامة والخطاب

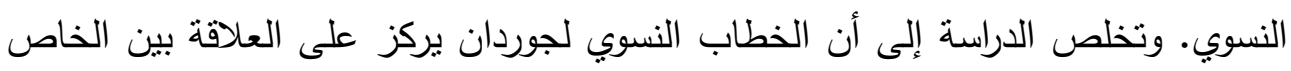
والسياسي والعام ويطور خطابًا عامًا قويًا يستطيع إصلاح اللامساواة المترسخة في وسائل الخطاب الشكلية الملوثة.

ولكونها شاعرة تتدرج تحت مظلة الموجة الثالثة النسوية ، تهتم جوردان بالصراع بين المرأة والهوية الديمقراطية لصياغة لغة شعرية جديدة لمعالجة القضايا العامة. وتتبنى جوردان نظرية النوع التي تبحث في مضامين الديمقراطية الاجتماعية والسياسية وتوضح الهوية النسوية ككيان مجتمعي.

كما يقدم شعر جوردان أيضًا نماذجًا جديدة للثاعرية الديمراطية ويبين كيفية تشكيل الواقع الاجتماعي لهوية الثاعر وتفككه من خلال تلك الهوية لطرح بدائل جديدة. الكلمات المفتاحية: الخطاب النسوي - الثاعرية الجنسانية الديمقراطية - النشاط السياسي - السياسي والخاص - العام وإلخاص - الموجة الثالثة النسوية 


\section{Introduction}

\subsection{Significance of the Study}

The American poet, June Jordan (1936-2002) was a poet, playwright, essayist, and professor of English at the University of California, Berkeley. Jordan has earned critical praise and popular recognition for her exceptional literary skill and her strong social and political insights. She is one of the widelypublished and highly-acclaimed African-American writers in history. Jordan believes that the role of the poet in society is to earn the trust of his/her audience and to be as honest and as careful as he/she possibly can.

This paper attempts to show Jordan's revolutionary spirit through her social commitment and conscientious activism, which are evident in her poems, and to prove that she is able to combine her social and political works and views with her personal life to serve public causes. In addition, the paper explains that Jordan uses conversational, often vernacular English, to address topics on family, political oppression, African-American identity and racial inequality. Her poetry highlights the African-American personal struggles of everyday life and the political oppression that this race is subjected to in a satirical style, which reflects the poet's bitterness and rage. Jordan uses Black English and irony to reflect a culture that is violent, anti-black, and anti-feminist. Her images combine different emotions and voices that reflect her wide-ranging aesthetic and human concerns. Jordan's poetry reflects her feminist advocation of human rights. Through her influential feminist vision, Jordan creates an "antiracist, antihomophobic US feminism" in an aesthetic form that is thematically "comprehensive, humane, and charged with conviction" ("June Jordan" 237). 
Jordan addresses shared human goals in search for a better society. Her poetry tackles issues related to identity and the recreation of the private/personal. It is associated with politics and foregrounds "a radical, globalized notion of solidarity amongst the world's marginalized and oppressed" (Phillips). She belongs to the "second renaissance" of African-American arts in the 1960s and 1970 s, as she is one of the initiators of the "cultural revival and the rise of the black consciousness in the 1960s" ("June Jordan" 236). Jordan bridges the gap between local and international issues, fights for humanity at large, opposes injustice that is rampant in the whole world, and calls for freedom for all the oppressed minorities. She draws attention to the "emotional, physical and political spaces required for the survival of marginalized peoples everywhere" (Kinloch 163-64). This is manifested in her commitment to the people in the US, Nicaragua, Lebanon, South Africa, Bosnia, Palestine, etc. This commitment enables her to discover the multicultural and multiracial identities as well as feminist politics, third-world activism, and power movements. Consequently, her dedication to freedom and to humanity at large has a provocative and strengthening effect on civil rights movements and the lives of disenfranchised women, children, and men. Jordan also plays a significant role in some of the major African-American political movements calling for the rights of women and for a democratic society.

The significance of studying Jordan's poetry is thus threefold. Firstly, her poetry examines the discursive assumptions or the discursive representation of democracy in the US culture. Secondly, it contributes to the democratic tradition in the US contemporary culture through the gender theory, which argues that citizenship and publicness are the main concepts of third-wave feminism. Thirdly, it suggests new kinds of democratic cultures by means of its variety of publics and its feminist discourse, which renews the possibilities of the democratic contract. 


\subsection{Democracy in the US and Third-Wave Feminism Alternatives}

This paper analyzes Jordan's contribution to the democratic tradition in the US contemporary culture through the recent gender theory, which argues about citizenship and publicness as the main concepts of third-wave feminism, in an attempt to reveal that her poetry suggests new kinds of democratic cultures by means of its variety of publics. In 2003, poetry emerged as a new sphere that investigated "national democratic culture" (Marsh 1). Advocating democracy in the US is twofold: it is characterized by unequal mechanisms, on the one hand, and the ideological, "semiotic relations of representation" (4), on the other. In this regard, Jordan attempts to question the US democratic culture by investigating its discursive assumptions or representation in the American culture.

Theories of US democracy adopt two perspectives: A laissez-faire liberalism, which advocates that liberty mean noninterference or any compulsion by force, and the republican tradition that reinforces political participation and active civic identity. Theorists of both sides, the Left (Liberals) and the Right (Republicans), strive to rescue the concept of democracy from the control of "institutional individualism" and to enhance the concept of the "democratic public sphere" (March 4). The Leftist attempts are divided between the public "rational deliberative models" and the more "radical agonal models" (4). Such attempts, with reference to critic Seyla Benhabib (1950- ), call for the active participation of collective identities. The Right side or conservative thinkers, with reference to the political theorist, Chantal Mouffe (1943- ), assume that the tension between equality and liberty provides the indefiniteness or indeterminacy that is essential for democracy. They believe that democracy threatens the religious power relations and fosters the concept of 
multiculturalism. Thus, it can be assumed that the Right (Republicans) adopts a more rational perspective of democracy.

All attempts to define modern democracy are as cultural as they are political. Ken Hirschkop argues that modern democracy, advocated by the Leftist perspective, is not only the outcome of the totality of power relations, but also of the intersubjective linguistic patterns that frame it (37). Thus, democracy is a discursive construct despite the existence of the freedom of speech. The intersubjective relations of US exceptionalism, aiming at constituting collective identities, can be traced in the poetry of various American poets, such as Walt Whitman, Robert Frost, George Oppen, William Carlos Williams and Robert Pinksy. Pinksy underlines the anti-poetic nature of US democracy as well as the intersubjectivity of poetry that represents democracy's fragile social contract - that is the presence or absence of an auditor. Therefore, such terms used in debates on democracy as "individual and collective, public and private, unity and difference, security and contingency" (Marsh 5) are essential in American poetry and specifically in the poetry of Jordan.

Gender is an integral part of the discussions about democracy since the dynamics of sexual politics obviously influence US democracy's nationalist discourses and women's relationship to the division between the public and the private that plays an exasperating role in the discourses of democracy. The Liberal and the Republican democratic traditions have opposite viewpoints; whereas the Liberals find freedom in the private, the Republicans find it in the public. The second-wave feminism deconstructs the political activities of liberalism in drawing a line between the public and the private. Feminist critics paid attention to the "masculinist content of the republican civic identity" (Marsh 5) or, in other words, the republican public masculine authority. Feminist theorist, Drucilla Cornell (1950- ), indicates that whatever is referred to as feminine is banned from the public 
sphere, which highlights how the feminine has thus become the guarding angel of discourses of US democracy (218). In this regard, theorists foreground the feminist discourse as significantly fundamental to renew the possibilities of the democratic contract as the issue of democracy can perfectly be examined through feminism. Feminist thinkers mainly focus on the relations between the private, the political, and the public and withdraw from the political and cultural processes of the masculine society to fall in the formalism of the feminist literary community.

Third-wave feminism has emerged as a social movement that has overhauled the late twentieth century with its emphasis on democratic cultures. It explores the problematic shift from feminism to democracy, taking into consideration both the rejection of the politics of resentment and the debates about "power" and "victim" feminism (Marsh 6). Most female poets, including Jordan, are concerned with the conflict between a feminist and a democratic identity in an endeavour to form a new poetic language for being public. This underlines how the gender theory examines the socio-political implications behind democracy, which foregrounds feminist identity as a societal construct.

Debates in democratic theory and third-wave feminism help investigate the way contemporary women poets negotiate the complexities of being public and how they are engaged with the heterogeneous social forms of poetry in addition to their suggested new possibilities for public culture. Although women poets examine the complex relationship between the private and the public as normative conventions of US democracy, "their writing and its cultural structures" attempt to find out alternatives for them (Marsh 10). Jordan, for example, recasts some of the established narratives for feminist poetics in her search for freedom. 
Unlike second-wave feminism, third-wave feminist movement is a radical anti-foundationalism that aims at deconstructing all the terms and aims of the second-wave feminism and constructing new meanings essential for the desires and strategies of third-wave feminists. Literature can mold new political possibilities for gender relations by making women of different backgrounds share a sense of communality/community and have the same identity at a time when difference dominates in contemporary feminism. In light of this, the following sections discuss Jordan as a third-wave, anti-foundationalist feminist.

Women poets have significantly contributed to modernist and late modernist experimental traditions, which resulted in particularly different and "increasingly expansive" literarypolitical vocabulary insofar as the visual, the aural, the crossmedia and performed poem have become clearer ever since (Marsh 15). Debates also rose on the private, the political and the public and their new meaning as the "literalism of identiterian critiques" has been abandoned and the "constitutive rather than the descriptive role of discourse" has become partially accepted (15). Feminist critics have given more energy to the democratic public subject in the post-feminist future overcoming existing divisions within feminism.

It has become evident that one of the basic tasks of thirdwave feminism is to create a strong public discourse capable of finding a remedy and reforming the inequality deeply implanted in the contaminated formative discourses.

\subsection{Jordan's Gendered-Democratic Poetic Space}

This part sheds light on Jordan's complementary critiques of the narrative of US democratic culture as well as examines her complex modeling of a literary counter-public. It also highlights Jordan's attempts to create new forms of a democratic public to demolish the political theorist Wendy Brown's (1955- ) concept 
of the "plastic cage" of institutionalized discourse and the impossible goal of freedom, and reflects Jordan's antifoundationalism in suggesting new models of a gendered democratic space. Jordan's poetry investigates the "discontinuities between the varied spaces of the public available to the African-American woman poet and gestures towards the possibility of alternatives" (Kinloch and Grebowicz 16). Thus, her poems offer a reinterpretation of the radical antifoundationalist critiques and multiculturalism liberal notions leading to the emergence of third-wave feminism.

Contemporary poet Kathleen Fraser (1935- ) mentions that poets of the second-wave feminist movement were attached to various post Second World War poetic movements, which highlights how their discourse served the status quo. She argues that the second-wave feminist movement did not trigger women's full self-expressions against oppression and marginalization neither in the poetic language they used nor in their artistic style. However, women's poetry that emerged in the late 1970s and continued throughout the 1980s shows that women poets were able to overcome the "double-bind" of aesthetic and social exclusion (31). This approach gives privilege to the female writing, like Jordan's, striving to overcome the inequalities legitimized by the separation between the public and the private. There were no longer any distinctions between the public and the private and the vocabulary has become neither static nor identitarian. However, the literary vocabulary used to represent the self was limited to forge an elusive unity of the public and private. Poets also tried to fight against the divided voice and to consolidate the tension between the "personal 'real' self" and the "strong poetic 'fantasy' self" that the androcentric literary culture insisted upon for the woman writer (Ostriker 80).

Jordan's poetry has no determinate meaning towards the public though she tries to reformulate its boundaries in her attempt 
to create her own alternative model for a gendered-democratic poetics. Jordan's model questions the limits of its discursive grounding and does not accept identity or the personal private as a basis for politics and remains completely focused on the social realities. When Jordan refers to the failed promises of US democracy, she turns to the largely disenfranchised global community characterized by inequality and exclusion. She realizes that identity cannot be a sufficient basis for politics. Jordan attempts to achieve an alternative by choosing the words that can show the difference between the common identities through which social and political realities are examined. Such individual identity, which would offer alternative realities in terms of language and thought, is deemed an endeavour to create an ethical language for individuality. It becomes evident in Jordan's poetry that social reality shapes the poet's identity and it is through this identity that reality is deconstructed and offered alternatives.

Jordan struggles for freedom though she knows that its institutionalized assumptions are inevitable for its realization, taking into consideration identity and power. Such knowledge on Jordan's part questions the "relations between democracy, gender, and poetics that strives for a literary counter-public whose efficacy derives from its incorporation, rather than its exclusion, of difference, of the economic, of the irrational" (Marsh 35). It is ultimately important to note that this attention to the public sphere's broad implications matches the theory of feminist democracy, illustrated by Fraser, which suggests one kind of possibility of a democratic model of feminist poetics (3536). Thus, it becomes clear that with Jordan a gendered democratic poetic space is taking place. 


\subsection{Fake Democratic Existence and Racial and Sexual Discrimination}

\subsubsection{Building black identity and cultural nationalism}

Jordan urges the blacks to establish a common culture by studying Black English and calls on the whites to give up on the idea that the Negro is the construct of racist white America. She encourages silent minorities to get together and "transform a 'tree' that has never really been planted or a movement that has not been fully actualized, into a discourse on a rhetoric of rights for disenfranchised people" (Kinloch 73). In her 1964 essay, "Letter to Michael," Jordan described the 1964 Harlem Riots to her husband and spoke of the police violence that shocked the black community, forcing it to realize that it is a minority. She criticized the police absurdities and violence that made the African-American community acknowledge that their suffering is real and provoked them to end their silence and protest against the immorality of their victimizers. Jordan employs a personal letter to serve a public purpose. She advocates the idea of an individual voice speaking from an African-American perspective rather than speaking on behalf of all African Americans.

In her essay, "Nobody Mean More to Me" (1988), Jordan declares that having the black people living in the American society resembles living in a house where every mirror reflects the face of someone who does not belong there and the way he/she walks or talks seems wrong. A reason for this is that the house, or America, shelters people who are hostile to black people. She writes that one becomes mature in a social body that does not tolerate his/her attempt to be different and forces $\mathrm{him} /$ her to become "clones of those who are neither our mothers nor our fathers" (160). She adds that the term Black English is not a linguistic threat, but rather it refers to a community of blacks that is marginalized from the social and political spheres 
of the American society, thus, its culture, language and everything else that signals its difference and intelligence are becoming extinct.

In addition, Jordan embodies the ideals and principles of the Black Arts Movement. The black artists who supported the black cultural traditions and artistic innovations in the black community include Poet-critics Amiri Baraka, Ed Bullins, Harold Cruse, Nikki Giovanni, Ron Karenga, Askia Muhammad, Larry Neal, and Sonia Sanchez. The aim of these writers is to create the black aesthetic, namely the existence of a powerful artistic and culture-based political collective that strives to reform current understandings of beauty and privilege, culture and power, and the philosophical principles of a black genius, or imagination, as related to black life, politics, and work through art (Kinloch 76). To affirm such aesthetic, black musicians, dancers, writers, filmmakers, poets, educators, dramatists, and even working-class labourers antagonized all the oppressive conditions they witnessed in America as represented in US imperialism, police violence, and other practices of racism against the blacks, in an attempt to achieve social reform.

Jordan attempts to bridge the gap between the old generation and the new generation of black poets by focusing on issues such as racism, classism, and sexism in both the literary and critical mainstream and the civil rights efforts in America. Though the work and principles of the Black Arts Movement have a great impact on Jordan's art and politics, she does not take any of this movement's poets as her mentor, but rather develops a voice of her own. Her writings mainly discuss black social and political concerns and she affects "a transition in the way that the black intellectual functions in American culture" (MacPhail 58). She is committed to civil rights, political opportunities, quality education, and better housing conditions for black people. She criticizes the works, philosophical teachings, and the political 
disposition of Martin Luther King (1929-1968), the Civil Rights Movement, and Malcolm X (1925-1965) and Black Power Movement. During the Civil Rights Era, Jordan rejected King's ideals or belief in nonviolence, benevolent love, integration, and the "Beloved Community" insofar as the blacks are obliged to stand up to segregation and all acts of violence. Jordan, thus, strongly believes that violence cannot be met with love and the white contempt must not be tolerated.

Jordan questions the validity of the political movements and their leaders. She seeks a politically committed international human rights movement that can represent the various experiences of women, men, and children with the aim of internationalizing "the black protest movement in its inclusivity" (Kinloch 85). In Civil Wars: Observations from the Front Lines of America (1981), Jordan expounds the lack of black leadership, King's assassination, and the black peoples' uprising in Miami. She suggests that black leadership, even during the 1980s, was "dangerous and tired" because of the increasing violent acts against people of colour. She thus claims, "Where is justice? Where is love? Where is leadership? Who is to be turned to for guidance? Who will stand up and lead the demonstrations, protests, and movements of resistance that once shaped black life in America? Is leadership really "dangerous and tired?" (37).

The mid- and late 1960s witnessed a drastic transformation in the African-American Civil Rights Movement. The AfricanAmerican social movements of the 1960s focused on black identity rather than the white victimization of blacks and hence there was a move towards cultural nationalism. Such movements developed from the "peaceful protests" that King called for to the "cultural nationalism" that was supported by the true revolutionary Malcolm X (MacPhail 59). This transformation is reflected in the rhetorical strategies of writers who influenced Jordan, such as Baraka. 
Jordan embraces the forceful strategies of Malcolm X and admires his magnificent oratorical skills and heated speeches, calling for social action and black cultural awareness. Though at the beginning she was only concerned with opposing the denial of black people's civil rights, she was later seeking justice for all people treated unjustly whether in America or elsewhere. Hence, her activist and political efforts developed from focusing merely on the civil rights of black people to an international context. Similarly, Malcolm X aspires to expand the civil rights movement into a human rights movement; hence internationalizing "the black freedom struggle" (Kinloch 80).

It is thus evident that Jordan's political experiences of the 1960s and 1970s were remarkably influenced, on the one hand, by the legacies of King, whom she perceives as a hero despite contradicting his nonviolent attitude at the beginning, and Malcolm X, who helped her foresee a new, different America, where equal rights prevail and there is no violence or hate. Their influence can still be traced in her poetry during the 1980s. After both leaders' assassinations, Jordan began to perceive the struggle for black people's liberation in light of other international civil rights struggles. Her enthusiastic involvement in political movements makes her believe that the lives of the blacks will be improved if people keep on marching, demonstrating and protesting to call for change. Therefore, Jordan's poems and political essays became more intense and full of rage, as they discuss power and empowerment, pride, survival as well as social and political advancement for the black community.

\subsubsection{Jordan's political activism and calling for democracy}

As a political activist, Jordan advocates that no single issue could be separated from the rest. She helps minorities, who may speak different languages, practice different religions and have 
different histories, to see themselves as connected to all the struggles for freedom in all places around the world. Jordan took part in a core Freedom ride, witnessed and reported on the Harlem Riots of 1964 and strongly insisted that one must resist any kind of injustice. She was involved in the 1960s Black Power Movement and her work as a political activist is indebted to this movement. She is "one of the fiercest and most compassionate voices of the twentieth century" (Pe'rez 326). In Civil Wars, Jordan illustrates the intersection of private and public reality, which she explores through blending personal reflection with the political analysis of such topics as freedom and civil rights to rally people into action.

The American poet Walt Whitman (1819-1892), who enabled Jordan to recognize the relation between America's failed promise of democracy and the alternative possibilities that poetry offers (Marsh 25), has a major influence upon her. She strongly believes that Whitman is the aesthetic voice of all people, the same role she assumes in her poetry. Whitman's "aesthetic democracy" dedicates the autopoetic dimensions of political life. He believes that "popular attachment to democracy requires an aesthetic component" and attempts to depict the needed "reconfiguration of popular sensibility through a poetic depiction of the people as themselves a sublimely poetic, worldmaking power" (Frank 402). Whitman seeks political regeneration in everyday citizenship poetics and ordinary life democratic potentials.

In her attempt to have a US that accepts diversity; multiculturalism; multilingualism; justice; and social, political and sexual freedom, Jordan is considered an apprentice of Whitman. In his poem, "Song of Myself" (1855), Whitman addresses themes that Jordan tackles in her collection of poetry Moving Towards Home (1989). In this poem, Whitman advocates comprehending the self as a spiritual entity that signifies both the individual and 
the universe. He, therefore, searches for ways to nurture man's mind and to build a strong relationship between the self and others or the surrounding community.

Jordan's poetry depicts the relationship between politics and representation and seeks to understand how the public sphere she is struggling for is formed. She fully understands that the democratic project requires rethinking of the tensions between identity and difference:

[r]ather than simply assuming the coincidence of "poem" and "political action" Jordan interrogates the potentially uneven match between her writing's insistent re-signification of the frames of representation and the more literal economic and pragmatic influences that controlled the thresholds for public participation. (Marsh 26)

Jordan advocates a pluralistic approach to poetry in her essay "For the Sake of a People's Poetry: Walt Whitman and the Rest of Us" (1980), where she antagonizes censorship and silencing minority voices in American literature. Whitman's influence and literary techniques are also evident in Jordan's "Poem About My Rights." Her writings show a "Whitmanesque wisdom" and as Kinloch argues they are like the melody that rearranges the connection between man and the universe as well as the obligations man has to the world. Jordan thus employs the lessons learned from Whitman to "serve a positive and collective function" (Kinloch 53).

Jordan's political activism and poetic visions are of utmost significance in a time of war resistance and the dream to achieve social justice, particularly after September 11 events and the continuous "War on / of Terror," where poets were required to take part in enlightening the people and confront all forms of violence prevalent in every aspect of human life. In Some of Us Did Not Die (2002), Jordan illustrates that fighting for equality and against violence never stops. She fought energetically for universal peace as she says, 
ONCE THROUGH the fires of September 11, it's not easy to remember or $O$ recognize any power we continue to possess.

Understandably we shrivel and retreat into stricken consequences of that catastrophe.

But we have choices, and capitulation is only one of them.

I am always hoping to do better than to collaborate with whatever or whomever it is that means me no good.

For me, it's a mind game with everything at stake....

Luckily, there are limitless, new ways to engage our tender, and possible responsibilities, obligations that our actual continuing coexistence here, in these United States and here, in our world, require. (8)

These lines epitomize Jordan's activist efforts and political stance in the last thirty-five years of her life. She is totally devoted to creating "new ways to engage people in a discourse of difference that would rebuild a world that embraces all perspectives, including women's and children's" (Kinloch 59). She thus introduces readers to the fact that the American life is threatened by social negligence, economic despair, and civil unrest.

\section{Jordan's Gendered-Democratic Poetics and Minority Rights}

From the mid-1970s, Jordan began to bring international issues to her poetry and to domestic audience. She identifies with the causes of the misrepresented, silenced and marginalized people, since she believes that they share her needs and experiences as an African-American woman living in the US (MacPhail 67). She started to address the issues of discrimination in terms of race and gender in addition to other political issues. Her writings speak for groups or individuals who were intimidated or marginalized to speak their own voice. She antagonized racism in the US, war in Vietnam and colonialism in Africa, which urged people to speak truth to power. Further, in the 1980s and 1990s, 
themes of discrimination, equality as well as social and economic inequality were still the focal point of her writings. Jordan addresses issues such as religious intolerance, global poverty, minority rights and America's foreign policy in countries such as Nicaragua and the Persian Gulf. She also discusses the ArabAmerican response to the situation in Palestine.

Furthermore, Jordan's collection of essays Technical Difficulties (1993) discusses the causes of the silenced and the marginalized. In these essays, Jordan uses her voice as an individual voice among many other voices that are fighting to gain power in the public forum. In this regard, Jordan's political writings are deemed "honest attempts to grab and redirect power" and her political essays in Technical Difficulties are "iconoclastic" as she links domestic to international political issues (MacPhail 67).

\subsection{Building Black Identity and Cultural Nationalism}

Jordan perceives that the past is essential to both the present and the future because having a better future depends upon healing the wounds and correcting the wrong doings of the past and the present. In her poem "Calling on All Silent Minorities," Jordan adopts some of Baraka's rhetorical strategies and responds to his poem "SOS" to awake and build the black community:

\section{HEY}

C'MON

COME OUT

WHEREVER YOU ARE

WE NEED TO HAVE THIS MEETING

AT THIS TREE

AIN' EVEN BEEN

PLANTED

YET (Directed by Desire 1-9) 
Here Jordan attempts to imitate Baraka in creating a community that only exists as a future projection and to give voice to a silent audience by the act of naming it. The audience Jordan addresses is highlighted by the pronoun "We" that involves the speaker who is black and thus one may think that she addresses a black audience. However, the title clearly illustrates that Jordan is neither interested in colour or in race nor in the exclusion of any minority and that she urges all minorities to speak out and indulge in the serious game of making their voices heard to build the community. This is foregrounded in her choice of the preposition "OUT," not "in" to grab the attention of her listeners to themselves as one coherent entity. Thus, like Baraka, she is committed to the idea of building a community by instilling its virtues in its audience.

Many incidents have contributed to Jordan's realization of her minority status. "Who Look at Me" (1969) gives a series of visual images of African Americans in one long poem where Jordan says:

Who would paint a people

black or white?

*

For my own I have held

where nothing showed me how

where finally I left alone

to trace another destination

*

A white stare splits the air

by blindness on the subway

in department stores

The Elevator

(that unswerving ride

where man ignores the brother 
by his side) ...

*

\section{Is that how we look to you}

a partial nothing clearly real? (Directed by Desire 1-20)

The poem depicts the Harlem riots that were provoked by a white policeman's shooting of a fifteen-year-old black male. This was an area where gunfire could be heard everywhere even among the masses of black people who gathered to eulogize the dead boy. Young people were ready to confront police officers and were determined not to keep silent of the violence committed against them by their own protectors. Events culminated in several rounds of gunfire, throwing grenade, verbal and physical abuse, and various causalities among innocent people. These riots urged Jordan to march in demonstrations and write poems seeking the rights of innocent civilians.

The poem seeks to reflect the interdependencies between social integration and visual and literary representation. This is manifested in the opening question: "Who would paint a people black or white?" The poem also tackles the modernist crisis in representation by depicting the "white stare" violence that "splits the air" with its blindness. In the poem, Jordan foregrounds the difference between the creation of image and ordinary representations. For instance, in the excerpt quoted above, Jordan refers to Charles Alston's painting Manchild, which draws the image of a black figure, adopting the cubist style in painting. Such style of paintings highlights ambiguity in its representation/mimeticism of reality, which is clearly reflected in Jordan's rhetorical question "is that how we look to you / a partial nothing clearly real." Another painting, which Jordan refers to in the same poem, is The Slave Market (1866), which she depicts twice. She refers to the painting as a whole before she starts to foreground the intricate patterns of a poor child, who is pulled by the hair from his own mother by a man who looks like 
a slave trader. The lexical she employs as in "(slavery:) the insolence" (148) suggests rage and contempt.

In an essay in The Progressive, Jordan combines the issues of race, gender, and class to discuss the case of Mike Tyson, the American professional boxer. On Tyson's experience, Jordan writes "Requiem for the Champ" (1992) where she links Tyson to her Brooklyn neighborhood that is barren and devoid of trees and claims that the violent lifestyle and the economic and spiritual poverty of the society surrounding him led him to the violent act of raping a woman. She explains that the issue of Tyson emanates from a larger social "atrocity" (Finn 124). Jordan believes that the Brooklyn community, the US economic system and herself are responsible for what Tyson committed. She elaborates that her culture must recognize the black man for other things than committed violence. She thus highlights, "I am Black. And Mike Tyson is Black. And neither one of us was ever supposed to win at anything more than a fight between the two of us" (Some of Us 86):

Do I believe he is guilty of rape?

Yes I do.

And what would I propose as appropriate punishment?

Whatever will force him to fear the justice of exact retribution, ...

And do I therefore rejoice in the jury's

finding?

I do not

Well, would I like to see Mike Tyson a

free man again?

He never was free! (85-86)

Thus, it is clear that Jordan blames the community as well as the economic structure for Tyson's violent attitude as a black man. She seeks the advancement, pride and empowerment of the black community. 


\subsection{Patriarchal Behaviour and Disempowerment of Black Women}

In 1978, Jordan wrote, "As a black woman, as a black feminist I exist, simultaneously as a part of the powerless and as a part of the majority peoples of the world" (Ransby, "June Jordan..."). As a feminist, she is considered a courageous, rebellious and compassionate poet, who cares for all humanity. On Aug. 9, 1987, Jordan read the poem "Poem for South-African Women" at the United Nations to commemorate the 40,000 women and children, who gathered, 22 years earlier, in the heart of South Africa apartheid capital to defy the "brutal and dehumanizing institution that divided their country" (Walrond 30). The poem praises their courage and sacrifice and indicates the African-American struggle for justice, equality and liberation at a time of political unrest. Jordan does not want to wait for a messiah-like figure to pave the way towards salvation, but rather perceives the change to be within the people's potential to impose social and political transformation. She says:

And who will join this standing up

and the ones who stood without sweet company

will sing and sing

back into the mountains and

if necessary

even under the sea

we are the one we have been waiting for

(Directed by Desire 29-35).

Jordan here refers to the South African women living under the apartheid, oppressive regime and fully believing that they are the ones who can free themselves rather than wait for their own demise. Those women and children, enduring painful experiences and living under restrictions of all kinds, understand that only the oppressed can free themselves and that they must take part in forging a new road towards their freedom and not to wait for outsiders to help in their liberation. 
Throughout her life, Jordan was keen on making the black community appreciate the black experience and the black culture, particularly that of black women, which is manifested in her collection, Passion: New Poems, 1977-1980 (1980). "Poem About My Rights" delineates her rage and disappointment at both racial and sexual discrimination. It opens with feelings of anger arising from her perceived "status as a woman alone in the evening":

Even tonight and I need to take a walk and clear my head about this poem about why I can't go out without changing my clothes my shoes my body posture my gender identity my age my status as a woman alone in the evening/ alone on the streets/alone not being the point

(Directed by Desire 1-6)

In this poem, Jordan does not care about being single. Rather she cares about the fact that many women and particular groups of people or countries have become known as the "Other" in the narratives of national identity. This is deemed a setback for the narrative of survival for people of colour, sense of belonging, and the myth of the American dream. She adds:

I am the history of rape

I am the history of the rejection of who I am

I am the history of the terrorized incarceration of myself

I am the history of battery assault and limitless armies against whatever I want to do with my mind (77-82)

Jordan's frustration becomes apparent as she establishes connections between personal aspects of human life and political struggles that humans should defy. She then acknowledges her ability to defend herself if necessary:

I am not wrong: Wrong is not my name

My name is my own my own my own and I can't tell you who the hell set things up like this but I can tell you that from now on my resistance my simple and daily and nightly self-determination may very well cost you your life (109-114) 
Jordan finally resists labels of "wrong" and substitutes political action with her own naming and freedom of choice.

Similar to her politically charged poems, in "Poem About My Rights" Jordan entices readers to ponder on the intensity of her argument and to fight against the restrictions patriarchy imposes on the female body. She wants action to be taken otherwise all theorizing about the injustices practiced against disenfranchised people is of no avail. The poem reflects the inability of women "to think in solitude, to be mesmerized by the silence of the night, and to embrace her skin, her identifying qualities, the way she desires to" (Kinloch 69) since she cannot do what she pleases to do with her body without facing the threat of physical rape and systemic violence.

In this context, "Poem About My Rights" discusses the violence that hinders peoples' and countries' democratic existence and impedes strengthening mutual choices and relationships between them. The poem derives its power from the sociopolitical connections Jordan establishes among womanhood, sexism, rape, politics, history, geography, economics, and identity to criticize abuses of power. On a larger scale, Jordan criticizes the inability of the black male leadership to stand up to its rhetoric and its disempowering of women. She believes that black women are disempowered by race.

Jordan believes that war is not merely a conflict between nations. The way she comprehends warfare reflects women's concept of war as represented by the feminist critic Jean Bethke Elshtain (1941-2013) who claims that women are enthusiastically patriotic and possess a kind of necessary maturity, which is vital to successful combat (xi-xii). Jordan explains in "Rape Is Not a Poem" and "Case in Point" that involvement of US troops in the Gulf War is not because of the newspaper stories of Iraqi soldiers' rape of Kuwaiti women since she believes that foreign 
policy can never depend on moral principles and that the American life has become warfare against women who have become fearful of physical abuse and rape. In these two poems, Jordan shows the connection between war and rape.

In her essay, "Notes Toward a Model of Resistance," Jordan emphasizes the notion of resistance and fighting against any form of domination such as sexual assault and acts of violence that stalk women on a daily basis. She writes about herself being raped twice (Some of Us 50-51). She reveals this fact in a 1994 interview with journalist Jill Nelson when she says:

I have been raped myself, twice. I happen to think rape as one of the most heinous things that can happen to anyone. But there's a victimization of people that is systematic....the media do not want to deal with that, they want to ignore the causative context that determines our lives, sometimes for great unhappiness and tragedy. (50)

This reflects her commitment towards universal justice as one of the issues she believes Media evade, such as racism, patriarchy, diversity, and sexism: "I had been unable to find within myself the righteous certainty that resistance requires, the righteous certainty that would explode my paralysis and bring me to an 'over my dead body' determination to stop his violence stop his violation of everything that I am" (Some of Us 51). Jordan's "righteous certainty" or "righteous rage" is different from the "masculinist and exclusivist edges of black-nationalist poetics" (172) that deny the female and non-black contributions to the struggle for justice and attribute them to the black male power. She advocates a "nationalist will-to-power" and sympathizes with the voiceless and the powerless in a style that is deemed an "exhortation to the voiceless and a cry of outrage against those who silence voices with their force" (172), particularly women's voice. 
In "Rape Is Not a Poem," Jordan talks about being raped for a first time in 1986 by a white man who, she says, "overpowered the supposed protection of my privacy, he had violated the boundaries of my single self. He had acted as though nothing mattered so much as his certainly brute impulse" (Technical Difficulties 14). Jordan opens the poem with reference to a beautiful garden that had been full of life, colours and sweet sensations before it was destroyed:

One day she saw them coming into the garden where the flowers live ...

they stamped upon and tore apart

the garden

just because (they said)

those flowers?

They were asking for it (Directed by Desire 1-12)

She refers to "they" to indicate those who destroyed the garden and its flowers as if they have deprived it of its virginal charm. Jordan calls this violation "rape" and she obviously refers to being raped herself:

I let him into the house to say hello ...

"Well, I guess I'll be heading out, again,"

he said.

"Okay," I answered and, "Take care," I said.

"I'm gonna do just that," he said.

"No!” I said: "No! Please don't. Please" (13-25)

The rapist left his victim defenseless and full of hatred towards men. It is this time when Jordan realized that there is no human autonomy and that one's safety can be jeopardized at any time. However, Jordan uses language to regain her right and power and instead of using the passive voice "I was raped," she uses the active voice "He raped me" (Some of Us 50) in an attempt to emphasize that language is the right tool to tell the truth about people who are abused and silenced by political regimes. 
The poem goes on to describe the gender-based persecution and the society that gives men the upper hand and degrades women:

\author{
And considering your contempt \\ And considering my hatred consequent to that \\ And considering the history \\ that leads us to this dismal place where (your arm \\ raised \\ and my eyes \\ lowered) \\ there is nothing left but the drippings \\ of power (33-41)
}

In the last two lines of the poem, it becomes clear that Jordan antagonizes the society that looks upon rape as something natural or justifiably normal: "Is this what you call / Only natural" (44-45) and that she hates that the female body is chosen for violent domination.

In "Case in Point," Jordan gives a powerful critique of masculine uses of power in the black community. The poem begins with "a friend of mine" who tells the speaker that "there is no silence peculiar / to the female" (Directed by Desire 1, 5-6). The speaker turns to narrate her second rape in 1996 by a "blackman actually / head of the local NAACP" (13-14). The NAACP is the "National Association for the Advancement of Colored People." It is ironical that this local national leader, who is supposed to protect the rights of coloured people, is the one who violates them. Jordan's anger is intensified by this act of human degradation, complete violence and violation of a female privacy.

Today is 2 weeks after the fact

of that man straddling

his knees either side of my chest

his hairy arm and powerful left hand

forcing my arms and my hands over my head

flat to the pillow while he rammed

what he described as his quote big dick

unquote into my mouth 
and shouted out: 'D'ya want to swallow

my big dick; well do ya?"

He was being rhetorical

My silence was peculiar

to the female. (15-27)

In this poem, the man's question is "rhetorical" as he assumes that he already knows the answer since he is powerful enough to form an answer without getting his addressee's consent. This is similar to "From the Talking Back of Miss Valentine Jones: Poem \# One" (1976) where powerful male speakers assume that they know what black women would say and hence there becomes no need for any kind of dialogue, be it political, social, or even personal. Jordan, instead of remaining a victim after the two raping incidents, finds a resort in writing and turning a personal issue into a public one. She compares between rape and state violence, and consequently, "posits a relationship of violence between the powerful - the state - and the powerless - women, children, and people of colour" (Kinloch 138).

In the long dramatic monologue "Miss Valentine Jones," Jordan protests against the assumption that black women have no voice and are completely ignored by black men, even the Black Arts Movement poets. Jordan highlights the liberations needed for the blacks in this poem. The title plays a major role in dedicating the rhetorical context of this poem, which is a part of a longer poem and is the first in a series of similar monologues. The title indicates the speaker, Valentine, informing the reader that it is an individual voice that speaks out for many other voices. Jordan makes Valentine criticize the naming strategies of "bodacious Blackm[e]n":

and the very next bodacious Blackman

call me queen

because my life ain' shit

because (in any case) he ain' been here to share it

with me

(dish for dish and do for do and 
dream for dream)

I'm gone scream him out my house

be-

cause what I wanted was

to braid my hair/bathe and bedeck my

self so fully because

what I wanted was

your love

not pity (Directed by Desire 71-85)

According to critic Scott MacPhail, "The male 'you' of the poem presumes that no 'real Miss Black America' has stood up, and that his words are the ones that will help her stand up" (65). Valentine names all the domestic routines that the bodacious black man neither sees nor valorizes in response to the male emptying up then filling in the notion of black womanhood. He knows nothing about the real duties carried out by other black women and consequently, they are not real. In addition to this lack of love from the "bodacious Blackman" for the working black woman, Jordan's poem points to the larger, more systemic failure by leaders of the Black movements to deconstruct images of blackness portrayed in popular white culture. For Jordan, a true black aesthetic could never really be actualized since some of the 1960s and 1970s political leaders did not fully take into consideration the voices and rights of black women and children.

In another poem, "Getting Down to Get Over: Dedicated to my mother" (1972), Jordan pinpoints the difficulties of feminizing the speaking voice. She seeks to voice and foster the various meanings attributed to black femininity: "momma Black / Momma / / Black Woman / Black / Female Head of Household / Black Matriarchal Matriarchy / Black Statistical / Lowlife Lowlevel Lowdown" (Directed by Desire 36-43). The poem focuses on the unstable signifying ground of black femininity and makes it clear in its linguistic assumptions. Having a list of single words makes the structures of linguistic meaning and their imagined voicing clear: "buck / jive / cold / strut / bop / split / tight / loose / close / hot / / hot / hot (139-150). 
The listing of verbs in this part clearly reflects a sexualized, racialized, and gendered movement. The contrast between synonyms such as ("jive," "strut," and "bop") and contrasts ("tight" and "loose," "hot and "cold") adds to the poem's intensity. In addition to showing the tensions between speech and writing as well as gender and race, the poem shows those tensions between selection/metaphor and combination/metonymy. Similar to Who Look at Me, the poem shows that the existing models of oral, literary, and visual representation are limited and seeks to expand its scope via other alternatives. Hence, Jordan attempts to have more expansive alternatives as opposed to politicized mimeticism.

Thus, it becomes obvious that through her poems about black female rights, Jordan offers a model of resistance and survival from all the incidents that bring fear and powerlessness into a female life. She does not want "brute domination" (Kinloch and Grebowicz 59) to become the norm according to which females live and understand American citizenship. She wants females to fight back.

\subsection{Repercussions of Imperial Racism}

Jordan sympathizes with all the marginalized in the world and this is exemplified in supporting the Iraqis and the Palestinians in the early 1980s and condemning the Israeli invasion of Lebanon in 1982. In addition, towards the end of the Persian Gulf War, she wrote her long poem, "The Bombing of Baghdad," where she strikes a comparison between bombing in that war and the US persecution of American Indians or Native Americans' genocide. Jordan writes her war resistance poetry as a community-building action, which foregrounds differences. Her poems are thus motivated by specific events, and are performed for and directed towards a particular audience. 
In "The Bombing of Baghdad," Jordan antagonizes war makers and imperial racism that give justifications for the Gulf War. It is based on the chant form that has become significant in the late twentieth century poetry as well as African-American cultural forms. This chant form helps Jordan clearly depict the relentless bombing campaign that lasted for 42 days and the human crisis resulting from the destruction. The poem alternates as "elegy, protest, and alternative wire service" (Metres 174) and moves the reader directly from the title of the poem to the heart of battle:

began and did not terminate for $\mathbf{4 2}$ days

and 42 nights relentless minute after minute more than 110,000 times

we bombed Iraq we bombed Baghdad we bombed Basra/we bombed military installations we bombed the National Museum we bombed schools we bombed air raid shelters we bombed water we bombed electricity we bombed hospitals we bombed streets we bombed highways we bombed everything that moved/we bombed Baghdad a city of 5.5 million human beings (Directed by Desire 1-14)

Jordan's delineation of the bombed targets and the suffering civilians who endured the repercussions of war becomes like a news story that is obviously ugly, truthful and uncensored. Her word selection serves a dual purpose by referring to her national community as well as the war devastated communities, which share the same destruction and the same destiny either by having the same passports, enduring the same taxes, or even watching the CNN. Jordan's usage of the pronoun "we" denies that there is any difference between the protesters and the patriots and provokes both of them to rebel. In terms of its communitybuilding function, "the poem acts as an admonishment to the community - whether imagined nationally or ideologically" (Metres 175). 
The poem represents two other narratives along with the bombing narrative: a personal lyric relating physical love and a historical narrative narrating the death of Crazy Horse, the 19th c. Native American war leader, and Custer's benefits. The personal lyric describes the priority and persistence of physical love: "The bombing of Baghdad / did not obliterate the distance or the time / between my body and the breath / of my beloved" (36-39) and the fact that the American citizens were not exposed to physical war. On the other hand, the historical narrative, pervading sections III to VI, illustrates the connection between the "guts and gore of manifest white destiny" (61) of Custer and US expansion and Iraq's bombing and expounds obvious, even treacherous, opposition. Jordan compares Crazy Horse's singing to "the moaning of the Arab World" (43) and declares defiantly that "I am cheering for the arrows / and the braves" (68-69) whose weapons are obsolete and who are doomed. The poem explains the genocidal inequality between the US and its enemies, whether they are Native Americans or Iraqis, that manifests itself after ruin and destruction have become a status quo.

In her poetry collection Living Room: New Poems 19801984 (1985), Jordan conceives her inevitable role as a poet in a time where media dominates. It includes politically motivated poems that indicate her memorializing impulses. Jordan's Living Room poems give a vivid image of the victimization of the Palestinians and the Lebanese during the Israeli invasion of Beirut in 1982. This is because, Jordan, as an Afro-American woman who witnessed the subordination of American blacks and as a geographically and culturally distant observer of the extermination of innocent civilians by American-made weapons, could shape readers' right perception of the genocide. Through the poems on Sabra and Shatila, Jordan aspires to destabilize the oppressive regimes and through her verbal images, she wishes to "inform the totality of living" (Ali 592). The images of the two 
camps of Sabra and Shatila represent Lebanon before and after their invasion in 1982. Before 1982, they were "the zone of hardihood, a sort of liminal space of hopeful waiting and readiness to return to the homeland," but after their devastation, they became "the zone of the trace of last movements, a sort of eschatological and conclusive space" (611).

Anxiety pervades in the tone of "The Cedar Trees of Lebanon" ("CTL"), "Apologies to All the People in Lebanon" ("AAPL"), and "Moving towards Home" ("MTH") as a result of sympathizing with the catastrophic event of Sabra and Shatila genocide that daily newspapers headlines shock readers with. Jordan does not want the subjects of her poems to be long forgotten, which is exactly the case with the media that begin by describing the genocide in Sabra and Shatila as "abominable," before undermining its horrific outcome (Ali 591). Her poems, in their representation of the genocide of Sabra and Shatila, would rather eternalize the massacre's horrible consequences on the victimized Palestinians.

Jordan's Sabra and Shatila poems are concerned spatially with the spaces that have become congested with corpses, debris, and shattered objects. They structurally represent the heinous details of torture and destruction or what she calls the "phosphorus events" ("CTL"17-18). In "AAPL," Jordan refers to the victims of US policy. Her language is the language of peace, as manifested in the offering of the hand, and the language of "negotiation."

Poet-activists Sara Miles and Kathy Engel organized an event in 1982 named after Jordan's poem "MTH" benefiting UNICEF's humanitarian efforts in Lebanon and supporting the worldwide efforts of mobilization. The event brought together several Arab, American and Israeli poets who talked about the harsh conditions and the suffering of the people in Lebanon as 
well as the massacre of Palestinians in Sabra and Shatila. In this event, Jordan read "MTH" where she announced:

\section{I was born a Black woman}

and now

I am become a Palestinian

against the relentless laughter of evil

there is less and less living room

and where are my loved ones?

It is time to make our way home. (Directed by Desire 72-78)

Jordan insists on the safe return "home" of displaced people without grief or wailing and talks about the value of human lives. She believes that the only way they can return home or symbolically return to the promise of freedom, liberty and love is by talking about home in public. By talking about home, Jordan emphasizes the sense of belonging to a world of justice and imagines a "Beloved Community" where people can enjoy safety, comfort and free will and where violence no longer exists.

"MTH" illustrates three psychic states: in the first 52 lines, the persona offers an all-encompassing visual net including various acts of atrocities. In this state, the overwhelmed poetic mind strives to assimilate the shock and indignation to bear such barbarities. Jordan says:

...the nightlong screams

that reached

the observation posts where soldiers lounged about

...the nurse again and

again raped

before they murdered her on the hospital floor (Directed by Desire 4-6, 21-22).

In the second state (53-71), Jordan emphasizes the "need to speak about living room" (54). In the last state (72-78), Jordan represents the reconceived self that sensed the suffering endured by the Sabra and Shatila victims.

Jordan's deep sadness towards the massacre of Sabra and Shatila is powerfully reflected in the syntactic parallelism she 
employs in "MTH." This is clearly seen in the phrase "nor do I wish to speak," which comes before every example of a brutal act to indicate genocidal barbarism. In the second state, she uses the phrase "I need to speak," merely to portray simple aspects of a moral world as in "the land is not bullied and beaten into / a tombstone" and "children will grow without horror" $(55-56,60)$. Consequently, the persona's feelings reach the climax as the reader approaches the finale of the poem: the wish of an ardent moral soul to "make our [all of suffering humanity] way home" (78). By this, Jordan attempts to represent the actual truth through the speaker's righteous anger towards the Israeli practices and brutalities that are unopposed by its allies.

In "MTH," the poetic voice speaks in the plural to illuminate the scope of "proliferation of absences" (Ali 614) unlike the paradigmatic female victim who speaks in the singular: "who will bring me my loved one?" When the poetic persona thoughtfully looks at the spacious, peaceful living room, she assumes, "where I can sit without grief without wailing aloud / for my loved ones," and "where the men / of my family between ages of six and sixty-five / are not / marched into a roundup that leads to the grave"; and at the poem's closure, she asks "and where are my loved ones?" (66-67, 61-64, 77). However, human absences are just one aspect of the oppressive series of absences the paradigmatic victim encounters such as her home or her living room, her homeland, and her political entity.

In "MTH," the name "Abu Fadi" assumes semantic significance since "Abu" means "father," indicating a unique Arabic naming system known as "Kunyah," then the name of his firstborn boy is added so that it can be used instead of his actual name. Jordan may have used the etymology of the name to relate it to moral desire. Fadi is a name that can be both a Muslim and a Christian name, meaning a "redeemer," one of Christ's attributes. Hence, the name Fadi also signifies a revered symbol to all 
humanity, namely Christ. This can be understood by the lines: "those [the people who refuse to be purified] are the ones from whom we must redeem / the words of our beginning" (51-52). These lines are a biblical allusion to the opening of the Gospel of John: "In the beginning was the Word, and the Word was with God, and the Word was God" (1:1). The "Word," referring to Christ, indicates that the moral world and its truths have been communicated to mankind.

Jordan's combination of "photography, sound/radio, journalistic text, and dissonant discourse in a dynamic interplay" confers upon her poems a "filmlike audiovisual capacity" that serves as a perfect representation of the complex socio-political reality of her time (Ali 615). For instance, in "MTH," Jordan's images are successively ordered in a "chain of [steadfast] kinetic sequential climatic scenes" that resembles the making of a film of violence (615). This is clearly reflected in the following lines:

the father whose sons

were shot

through the head while they slit his own throat before

the eyes

of his wife (10-14)

The same sequence of images is also reflected in the lines: "the pounding on the / doors and / the breaking of windows and the hauling of families into / the world of the dead" (27-30) and "the bulldozer and the / red dirt / not quite covering all the arms and legs" (31-33). Thus, it becomes clear that Jordan takes the kinetics of images technique from films so as to give the reader a spectatorial experience.

Thus, it becomes clearer that through her war-resistance poetry, Jordan seeks to build the "Beloved Community" where there are no differences between the people of the world. She antagonizes war makers and imperial racism that justify the brutal acts and atrocities endured by innocent civilians everywhere. Jordan unifies all humanity in one public identity 
that suffers the repercussions of war, genocide, etc. and provokes the oppressed to rebel.

\subsection{Political Rights and Fake Democratic Existence}

Jordan strongly believes that poetry plays a significant role in building the self, the community and a democratic state where there is mutual trust between citizens of the same country. The US politics has shaped Jordan's idea of leadership as she is totally convinced that the failed attempts of mobilization in underserved communities are directly linked to the American Republicans' and Conservatives' political agenda, particularly under the leadership of President Ronald Reagan. Jordan is shocked at Reagan's controversial stance with regard to the people victimized by either greed, oppression, or imperialism in light of the legacy he creates for himself - that is called, the "Reagan Revolution." Jordan wants the leader to stop imposing new taxes for the sake of people's prosperity and she is amazed at leaders, pretending to call for a world where there is no war, violence, or brutality, while they are stockpiling nuclear weapons.

In her poem, "Easter Comes to the East Coast: 1981," Jordan addresses President Reagan and speaks about a world where diversity and egalitarianism are present:

Don' you worry about a thing

Mr. President and you too

Mr. Secretary of the State: Relax!

We not studying you guys:

NO NO NO NO NO!

This ain' real

Ain' nobody standing around

We not side by side

This ain' no major league rally

We not holding hands again

We not some thousand varieties of one fist!

This ain' no coalition

This ain' no spirit no muscle no body to stop the bullets

We not serious (Directed by Desire 1-14) 
The message Jordan delivers to the President and his cabinet members reflects her stance towards the civil movements during the 1980 s as well as the labour movements that give advantage to certain groups over others. Jordan negates aspects of history, as she believes that nobody is watching, paying attention, or joining hands, when, actually, people are watching and organizing, since there is need to worry about the long-term implications of US politics. The poem goes on:

NO NO NO NO NO!

And I ain' never heard about El Salvador;

I ain' never seen the children sliced

and slaughtered at the Sumpul Riverside

And I ain' never heard about Atlanta;

I ain' never seen the children strangled in the woods ...

NO NO NO NO NO!

This is just a fantasy.

We just kidding around

You watch! (15-31)

Jordan wishes for a new world of diversity and egalitarianism. She believes that the Americans are behind the increased violence, not only on the national level, but also on the world level, thanks to Reagan's regime that insists on using nuclear power and producing more fatal bombs.

Reagan assumed power in 1980 and remained in office till 1988. He was opposing the Soviet Union over issues of communism. The Soviet Union was supporting Cuba in the 1980s, while the US government refused to support the Cuban liberation. Further, the threat of nuclear war was still in the air and Jordan was well aware of it. Jordan writes in her poem "A Reagan Era Poem in Memory of Scarlet O'Hara, who said, in Gone With the Wind, something like this:"

"As God is my witness, so help me God:

I'm going to live through this

And when it's over

If I have to lie, steal, cheat, or kill,

I'll never go hungry again." 
The poem says:

“Amen!" (Directed by Desire 1-7)

In another poem, "Where Are We and Whose Country Is This, Anyway?" (1986), Jordan exclaims that America needs a new president and opposition. She wants the new president to care for Nicaragua's Sandinistas (members of National Liberation Front), all African peoples, and the American citizens. Therefore, she wishes for a new political agenda for the democratic country that does not accept ethnic cleansing or genocide. The same notion is further highlighted in "INTIFADA INCANTATION: POEM \#8 FOR b.b.L" (1997), where she writes:

\section{SAID I LOVED YOU AND I WANTED \\ GENOCIDE TO STOP \\ I SAID I LOVED YOU AND I WANTED AFFIRMATIVE \\ ACTION AND REACTION \\ I SAID I LOVED YOU AND I WANTED MUSIC \\ OUT THE WINDOWS \\ I SAID I LOVED YOU AND I WANTED \\ NOBODY THIRST AND NOBODY \\ NOBODY COLD (Directed by Desire 1-9)}

In this chant-like poem, Jordan engages in an uprising or "Intifada," a word that was coined after the Palestinian uprising against the Israeli military rule in 1987. What Jordan antagonizes is not only military oppression, but also all inhumane conditions including "genocide," "thirst," and "cold" that jeopardize people's life worldwide. She calls for "action," "reaction," "music," and "love" instead. She wants to demolish all the boundaries that foster human inequality, suffering, fear, and oppression. This strengthens the idea of a "Beloved Community" where there are no borders and where human rights prevail. She adds:

I SAID I LOVED YOU AND I WANTED I WANTED

JUSTICE UNDER MY NOSE

I SAID I LOVED YOU AND I WANTED

BOUNDARIES TO DISAPPEAR

…

I WANTED 
The poem reflects a "politics of rejection," where all attempts against the practices of oppression by the state are overlooked (Kinloch 90). Throughout her life, Jordan aspires for freedom and liberation. She does not wish to remain "inside the big and messy and combustible haystack of these United States, and the forecast is not good" (Technical Difficulties 93).

In another poem, "To Free Nelson Mandela," from Naming Our Destiny (1989), Jordan declares:

Have they killed the twelve-year-old-girl?

Have they hung the poet?

Have they shot down the students?

Have they splashed the clinic the house

and the faces of the children

with blood? (Directed by Desire 7-12)

This poem builds on the theme of being "wrong," since the poet employs repetition to attack dominant beliefs about the undesirability and unworthiness of "the twelve year-old," "the poet," "the students," and "the children." This notion goes in line with the apartheid, Mandela's imprisonment and the longawaited freedom, his strong wife and the community that refused to succumb to the brutalities and atrocities of the ruling government: "Every night Winnie Mandela / Every night the waters of the world / turn to the softly burning / light of the moon" (13-16). The poem continues to show that injustices can lead to communities that reject silence and dehumanization. Jordan concludes by having "the carpenters," "the midwives," "the miners," "street sweepers, "the diggers of the ditch," (36-40) and other community members memorialize the murder of South African activists in the township of Lingelihle. Kinloch believes that documenting this act of remembrance "speaks volumes to Jordan's attack on institutional silence through a politics of inclusion that values and validates the multiple experiences of people" (71). 
Jordan becomes totally immersed in the experience of disenfranchised people. The murders carried out by the police in South Africa and the resultant violence around the world. For instance, the murder of Victoria Mxenge in "To Free Nelson Mandela" and the violence in "Namibia," "Angola," or "Zimbabwe" in "Poem About My Rights" were events that Jordan was desperately keen on writing about and share with others to provoke political activism and encourage people to take action. Both "To Free Nelson Mandela" and "Poem About My Rights" reveal that people's lives depend on the actions taken by responsible, dedicated leaders. Both poems "combine lyricism with narrative and free verse in a journalistic story form" (Kinloch 71) and they capture the intensity of lives destroyed by racism, violence, and classism. They reflect Jordan's racial solidarity and keenness on protecting human life.

Consequently, it becomes evident that Jordan calls for freedom and liberation and that her poetry plays a major role in building the self, the community and the democratic state where human rights prevail. She severely antagonizes political leaders who victimize people by greed, oppression or imperialism and only care about compiling lethal weapons. Jordan dreams of demolishing all the boundaries that foster human inequality, suffering, oppression and fear.

\section{Conclusion}

In conclusion, Jordan approaches the African-American causes in a way that best serves the African-American community that is diverse, yet can be united in opposing the inequalities of power resulting from race politics. She does not limit herself to the model of a spokesperson and makes the Black Arts utopian vision more attainable and pragmatic. Jordan obviously opposes racism, sexism and oppression, as she fosters the notion that individual creativity and honest discourse can lead to political change and 
social renewal. Her poems remarkably manifest the AfricanAmerican experience and advocate self-determination and political activism for the betterment of the community and the oppressed all over the world. She is sincerely dedicated to human rights on a global scale and political manifesto.

Jordan, in this respect, "employ[s] democratic and uncensored language in order to convey,..., truths about race, gender, sexuality, violence, war, and human rights" (Kinloch 1). She describes the difficulty of living in America as a raced and gendered person facing injustices and depicts the atrocities inflicted upon people in different countries. Thus, she dedicates her life to fight for freedom and justice for all humanity. Her writings are "politically savvy and unconventional in its brutal honesty" (2) since she deems it inevitable to fight for both equality and freedom.

Jordan's political and activist efforts show the brilliance of such an American writer, not only as a black woman, but also as a poet who cares for the humanitarian rights of peoples throughout the world and who clearly has a defined purpose. She utilizes both the written and spoken word to encourage return to the basic elements of human rights including, "civil liberties, fair treatment, education and literacy, and access to the political process" and she endeavours to demolish political systems that "challenge democratic order and perpetuate global injustice" (Kinloch 92). In this context, Jordan proves to be a serious artist and a revolutionary activist whose embracing of human rights are truly reflected in her poetry and dedication to political and activist work. Her poetry projects her total awareness of identity politics where her personal involvement with the world experiences found a real platform through the poems she writes on the misery of the disenfranchised worldwide. 
Jordan's figurative images, powerful words, and democratic language, which speak for many marginalized voices, convey hope of liberation. Her language enables her to know her selfidentity as a revolutionary artist. She made political statements in all the countries she travelled to; in all the rallies and demonstrations she took part in; and in all the efforts to put an end to the underrepresentation of black women, the unjust treatment of black people, and the atrocities inflicted upon the Lebanese and the Palestinians; and politicians' imperialistic agendas. Indeed, as a revolutionary writer, Jordan does not tolerate violence and inequality and protests against the systems she opposes on both the political and the personal levels. 


\section{Works Cited}

Ali, Zahra A. Hussein. "Aesthetics of Memorialization: The Sabra and Shatila Genocide in

the Work of Sami Mohamad, Jean Genet, and June Jordan."

Criticism, Fall 2009, vol. 51, no. 4, pp. 589-621. ISSN: 0011-1589.

Cornell, Drucilla. "Gender Hierarchy, Equality and the Possibility of Democracy." Feminism

and the New Democracy: Re-Siting the Political, edited by Jodi

Dean, Sage, 1997, pp. 210-221.

Elshtain, Jean Bethke. Women and War. U of Chicago P, 1995.

Finn, Paula. "June Jordan's Legacy: Will Labor Accept the Gift?" New

Labor Forum, vol.

12, no. 1, Spring 2003, pp. 123-127.

$<$ http://www.jstor.org/stable/40342394>

Accessed: 22-12-2016 16:22 UTC.

Frank, Jason. "Aesthetic Democracy: Walt Whitman and the Poetry of the People." The

Review of Politics, vol. 69, 2007, pp. 402-430. DOI:

10.1017/S0034670507000745

Fraser, Kathleen. "The Tradition of Marginality." Translating the

Unspeakable: Poetry and

the Innovative Necessity. Alabama UP, 2001, pp. 25-38.

Jordan, June. "Nobody Mean More to Me than You and the Future Life of Willie Jordan."

Reading Culture: Contexts for Critical Readings and Writing, edited

by Diane George and John Trimbur, Pearson/Longman, 2007, pp.

160-169.

---. Directed by Desire: The Collected Poems of June Jordan, edited by Jan Heller Levi and

Sara Miles, Copper Canyon Press, 2005.

---. Some of Us Did Not Die: New and Selected Essays, Civitas Books, 2002.

---. Civil Wars: Observations from the Front Lines of America, Touchstone Books, 1995.

---. Technical Difficulties, Trafalgar Square, 1993.

---. Who Look at Me, Thomas Y. Cromwell Company, 1969.

"June Jordan." The Concise Oxford Companion to African American Literature, edited by

William L. Andrews, Frances Smith, and Foster Trudier Harris, Oxford UP, 2001.

Hirschkop, Ken. Bakhtin: An Aesthetic for Democracy, Oxford UP, 1999. 
Kinloch, Valerie. June Jordan: Her Life and Letters, Praeger, 2006.

Kinloch, Valerie, and Margret Grebowicz. Still Seeking an Attitude: Critical Reflections on

the Work of June Jordan, Lexington, 2004.

MacPhail, Scott. "June Jordan and the New Black Intellectuals." African

American Review,

vol. 33, no. 1, Spring, 1999, pp. 57-71.

$<\mathrm{http}: / /$ www.jstor.org/stable/2901301>.

Accessed: 22-12-2016 16:23 UTC.

Marsh, Nicky. Democracy in Contemporary U.S. Women's Poetry, American Literature

Readings in the 21 st Century, Ser. Ed. Linda Wagner-Martin,

Palgrave Macmillan, 2007.

Metres, Philip. "June Jordan's War Against War." Peace Review, vol.15, no.2, 2003, pp.

171-177. DOI: 10.1080/1040265032000102068

Nelson, Jill. "A Conversation with June Jordan." Quarterly Black Review of Books, vol.1, no.

4, May 1994, p. 50.

Ostriker, Alicia. Stealing the Language: The Emergence of Women's Poetry in America,

Beacon Press, 1986.

Pe'rez, Roy. "June Jordan (1936-2002).” Encyclopedia of African American Women Writers,

vol. 1, edited by Yolanda Williams Page, Greenwood Press, 2007.

Phillips, Gwen. "June Jordan: Poet Details 1936-2002."

$<$ https://www.poetryfoundation.org/poems-and-

poets/poets/detail/june-jordan>. Accessed: 16/12/2016.

Ransby, Barbara. "June Jordan: A Life of Poetry, Politics and Passion."

June 25, 2002.

$<$ http://www.progressive.org/media_1529>. Accessed: 22/12/2016.

Walrond, Michael Jr. "Religion and Spirituality." The New York Amsterdam News, 25 Feb-2

March, 2016, p. 30. 
74 